\title{
Nelfinavir Induces Endoplasmic Reticulum Stress and Sensitizes Renal Cancer Cells to TRAIL
}

\author{
KAZUKI OKUBO, AKINORI SATO, MAKOTO ISONO, TAKAKO ASANO and TOMOHIKO ASANO \\ Department of Urology, National Defense Medical College, Tokorozawa, Japan
}

\begin{abstract}
Background/Aim: Induction of endoplasmic reticulum (ER) stress is a novel strategy for cancer treatment. The human immunodeficiency virus protease inhibitor nelfinavir was recently shown to induce ER stress, but its anti-neoplastic activity has never been investigated in renal cancer, as far as we are aware. Materials and Methods: Using renal cancer cells (769-P, 786-O, Caki-2), the ability of nelfinavir to induce ER stress and sensitize them to tumor necrosis factor-related apoptosis-inducing ligand (TRAIL) was tested. Results: Nelfinavir caused apoptosis and inhibited renal cancer growth in a dose-dependent fashion. It also suppressed colony formation significantly. Nelfinavir induced ER stress and increased the expression of TRAIL death receptor $(D R) 4$ and DR5, sensitizing the cancer cells to TRAIL. This sensitization was blocked by human recombinant $D R 4 / F c$ and $D R 5 / F c$ chimeric protein, confirming that the sensitization was due to increased expression of both DR4 and DR5. Conclusion: Nelfinavir induces ER stress in renal cancer cells and sensitizes them to TRAIL.
\end{abstract}

It has been estimated that in 2012 there were over 330,000 new cases of renal cancer, resulting in more than 140,000 deaths worldwide (1). Although molecular targeted drugs, such as tyrosine kinase inhibitors and mammalian target of rapamycin (mTOR) inhibitors, have a significant antitumor effect and improve the survival rates of patients with advanced renal cancer, they are not curative agents (2-7). Immune checkpoint inhibitors have recently been approved and widely used, but their therapeutic effect is also limited $(8,9)$. Renal cancer, thus, remains a lethal disease, and a more effective treatment modality needs to be developed.

Causing unfolded protein accumulation and endoplasmic reticulum (ER) stress is a novel approach to cancer treatment

Correspondence to: Akinori Sato, Department of Urology, National Defense Medical College, 3-2 Namiki, Tokorozawa, Saitama 3598513, Japan. Tel: +81 429951676, Fax: +81 429965210. E-mail: zenpaku@ndmc.ac.jp

Key Words: Nelfinavir, endoplasmic reticulum stress, tumor necrosis factor-related apoptosis-inducing ligand, renal cancer.
(10). Nelfinavir is a human immunodeficiency virus (HIV) protease inhibitor approved by the Food and Drug Administration for the treatment of patients with HIV; it increases unfolded proteins by suppressing the function of proteasomes and molecular chaperones such as heat-shock protein 90 (HSP90) $(11,12)$, thereby causing ER stress.

Tumor necrosis factor (TNF)-related apoptosis-inducing ligand (TRAIL) is a cytokine produced by most normal tissue cells (13). It binds to the death receptors DR4 and DR5 and causes apoptosis of cancer cells (14). Interestingly, ER stress induction has recently been shown to increase the expression of these DRs (15).

In the present study, we investigated the ability of nelfinavir to induce ER stress in renal cancer cells and sensitize them to TRAIL by increasing the expression of the death receptors DR4 and DR5.

\section{Materials and Methods}

Cell cultures. Human renal cancer cells (769-P, 786-O, and Caki-2) were purchased from the American Type Culture Collection (Rockville, MD, USA) and cultured in Roswell Park Memorial Institute medium or McCoy's 5A medium containing $10 \%$ fetal bovine serum and $1.0 \%$ penicillin/streptomycin (Invitrogen, Carlsbad, $\mathrm{CA}, \mathrm{USA})$ at $37^{\circ} \mathrm{C}$ under $5 \% \mathrm{CO}_{2}$ in a humidified incubator.

Reagents. Nelfinavir purchased from Tocris Bioscience (Bristol, United Kingdom) was dissolved in dimethyl sulfoxide. Human recombinant TRAIL, DR4/Fc, and DR5/Fc chimeric protein were purchased from R\&D Systems (Minneapolis, MN, USA) and dissolved in sterile phosphate-buffered saline (PBS) containing $0.1 \%$ bovine serum albumin. These agents were stored at $-80^{\circ} \mathrm{C}$ until use.

Evaluation of the effect of nelfinavir on cell viability. A total of $5 \times 10^{3}$ cells were plated in a 96-well culture plate 1 day before being treated with 2-20 $\mu \mathrm{M}$ nelfinavir. Cell viability was evaluated by MTS assay (CellTiter 96 Aqueous kit; Promega, Madison, WI, USA) according to the manufacturer's protocol. The experiment was performed using 12 wells per concentration and repeated three times.

Colony-formation assay. A total of 150 individual cells were seeded in 6-well plates 1 day before being treated for 48 hours with 5-20 $\mu \mathrm{M}$ nelfinavir. The cells were then given fresh media and cultured for 1-2 
weeks. The colonies were fixed with $100 \%$ methanol, stained with Giemsa's solution, and counted.

Evaluation of the effect of nelfinavir on the cell cycle. A total of $1.5 \times 10^{5}$ cells were seeded in a 6 -well culture plate 1 day before treatment. They were then cultured for 48 hours with 5-20 $\mu \mathrm{M}$ nelfinavir. Changes in the cell-cycle distribution were evaluated using flow cytometry.

Evaluation of nelfinavir-induced apoptosis. A total of $1.5 \times 10^{5}$ cells were seeded in a 6-well culture plate 1 day before being treated for 48 hours with 10 or $20 \mu \mathrm{M}$ nelfinavir. Apoptotic cells were detected by annexin- $\mathrm{V}$ assay using flow cytometry. The experiment was repeated three times.

Aggresome detection. Protein aggregation caused by nelfinavir was evaluated by detecting aggresomes in the cells. Briefly, $1.5 \times 10^{5}$ cells were seeded in a 6 -well culture plate 1 day before being cultured for 48 hours in medium containing 10 or $20 \mu \mathrm{M}$ nelfinavir. Cells were then fixed, permeabilized, and incubated with Hoechst 33342 and PROTEOSTAT dye (Enzo Life Sciences, Farmingdale, NY, USA) according to the manufacturer's instructions. Aggresomes were then qualitatively visualized by fluorescence microscopy.

Evaluation of the combined effect of nelfinavir and TRAIL on cell viability. A total of $5 \times 10^{3}$ cells were plated in a 96-well culture plate 1 day before treatment. They were then cultured for 24 hours in medium with or without $20 \mu \mathrm{M}$ nelfinavir before being given $25 \mathrm{ng} / \mathrm{ml}$ TRAIL with or without $1 \mu \mathrm{g} / \mathrm{ml} \mathrm{DR} 4 / \mathrm{Fc}$ or $\mathrm{DR} 5 / \mathrm{Fc}$ chimeric protein and incubated for another $24 \mathrm{~h}$. Cell viability was evaluated by MTS assay as described above. The experiment was performed using 12 wells in each condition and repeated at least twice.

Evaluation of the combined effect of nelfinavir and TRAIL on apoptosis induction. A total of $1.5 \times 10^{5}$ cells were seeded in a 6-well culture plate 1 day before treatment. They were cultured for 24 hours in medium with or without $20 \mu \mathrm{M}$ nelfinavir before being given 25 $\mathrm{ng} / \mathrm{ml}$ TRAIL with or without $1 \mu \mathrm{g} / \mathrm{ml} \mathrm{DR} 4 / \mathrm{Fc}$ or DR5/Fc chimeric protein and incubated for another $24 \mathrm{~h}$. Apoptotic cells were detected by annexin- $\mathrm{V}$ assay using flow cytometry. The experiment was repeated three times.

Flow cytometry. Flow cytometry was used to evaluate changes in the cell-cycle distribution and apoptosis. Briefly, cells were washed with PBS and harvested by trypsinization. For cell-cycle analysis, harvested cells were resuspended in citrate buffer and stained with propidium iodide. For apoptosis analysis, cells were stained with annexin $\mathrm{V}$ and 7-amino-actinomycin $\mathrm{D}$ (7-AAD) according to the manufacturer's protocol (Beckman Coulter, Marseille, France). They were then analyzed by flow cytometry using the CellQuest Pro software (BD Biosciences, San Jose, CA, USA). A total of 10,000 cells were counted.

Western blotting. Cells were treated for $48 \mathrm{~h}$ with 5-20 $\mu \mathrm{M}$ nelfinavir and whole-cell lysates were obtained using radioimmunoprecipitation assay buffer. Equal amount of proteins was separated by $12.5 \%$ sodium dodecyl sulfate-polyacrylamide gel electrophoresis and transferred to nitrocellulose membranes. After the membranes were blocked by $5 \%$ skimmed milk, they were incubated overnight with primary antibodies to cyclin D1 (sc-753, 1:500), cyclin-dependent kinase (CDK) 4 (sc-601, 1:500), survivin (sc-10811, 1:500), DR4 (sc7863, 1:500), DR5 (sc-65314, 1:500), and glucose-regulated protein (GRP) 78 (sc-7865, 1:500) (Santa Cruz Biotechnology, Santa Cruz, CA, USA); cleaved poly(ADP-ribose) polymerase (PARP) (\#9541, 1:1000), endoplasmic oxidoreductin-1-like protein alpha (ERO1-L $\alpha)$ (\#3264, 1:1000) and endoplasmic reticulum resident protein (ERp) 44 (\#3798, 1:1000) (Cell Signaling Technology, Danvers, MA, USA); light chain (LC) 3 (PM036, 1:2000) (MBL International, Woburn, MA, USA), phorbol-12-myristate-13-acetate-induced protein 1 (NOXA/PMAIP1; ab13654, 1:500) (Abcam, Cambridge, UK); or actin (MAB1501, 1:4000) (Millipore, Billerica, MA, USA). They were then incubated with horseradish-tagged secondary antibodies (Bio-Rad, Hercules, CA, USA). The bands were visualized by chemiluminescence with the ECL Plus system (GE Healthcare, Wauwatosa, WI, USA) according to the manufacturer's instructions.

Statistical analysis. The statistical significance of observed differences between samples was determined using the MannWhitney $U$-test (JMP pro13 software; SAS Institute, Cary, NC, USA). Differences with $p<0.05$ were considered be statistically significant.

\section{Results}

Nelfinavir had anti-proliferative activity against renal cancer cells. According to the cell viability assay, nelfinavir inhibited the growth of renal cancer cells in a dosedependent fashion (Figure 1A). We then investigated whether nelfinavir affected the clonogenic survival of renal cancer cells and found that it inhibited their colony formation in a dose-dependent fashion (Figure 1B).

Nelfinavir induced apoptosis of renal cancer cells. The effect of nelfinavir on the cell cycle was then examined. In all the cell lines, nelfinavir increased the number of the cells in the sub- $\mathrm{G}_{1}$ fraction (Figure $2 \mathrm{~A}$ ), suggesting that nelfinavir induced apoptosis. We also found that it markedly reduced the expression of cyclin D1 and CDK4 (Figure 2B), which was consistent with the observed cell-cycle changes. Nelfinavir increased the number of annexin-V-positive cells in a dosedependent fashion (Figure 2C). It also increased the expression of cleaved PARP and NOXA and reduced the expression of survivin (Figure 2D), an anti-apoptotic protein associated with cell proliferation in renal cancer (16). Thus, nelfinavir was shown to induce apoptosis of renal cancer cells.

Nelfinavir induced ER stress in renal cancer cells. Next, we evaluated the changes in the expression of the ER stress markers GRP78, ERO1-L $\alpha$, and ERp44. In all the cell lines, nelfinavir increased the expression of these markers in a dose-dependent fashion (Figure 3). Thus, nelfinavir was shown to induce ER stress. Furthermore, nelfinavir increased the expression of NOXA (Figure 2D), indicating that the ER stress induced by nelfinavir caused apoptosis. 
A

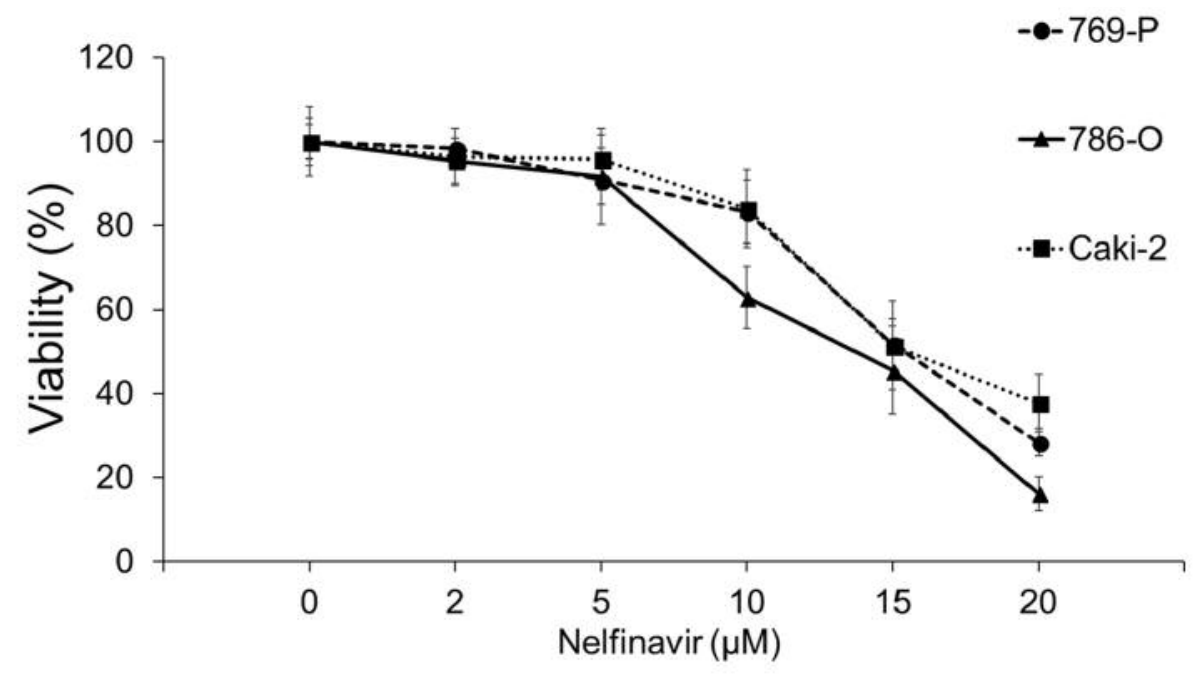

B

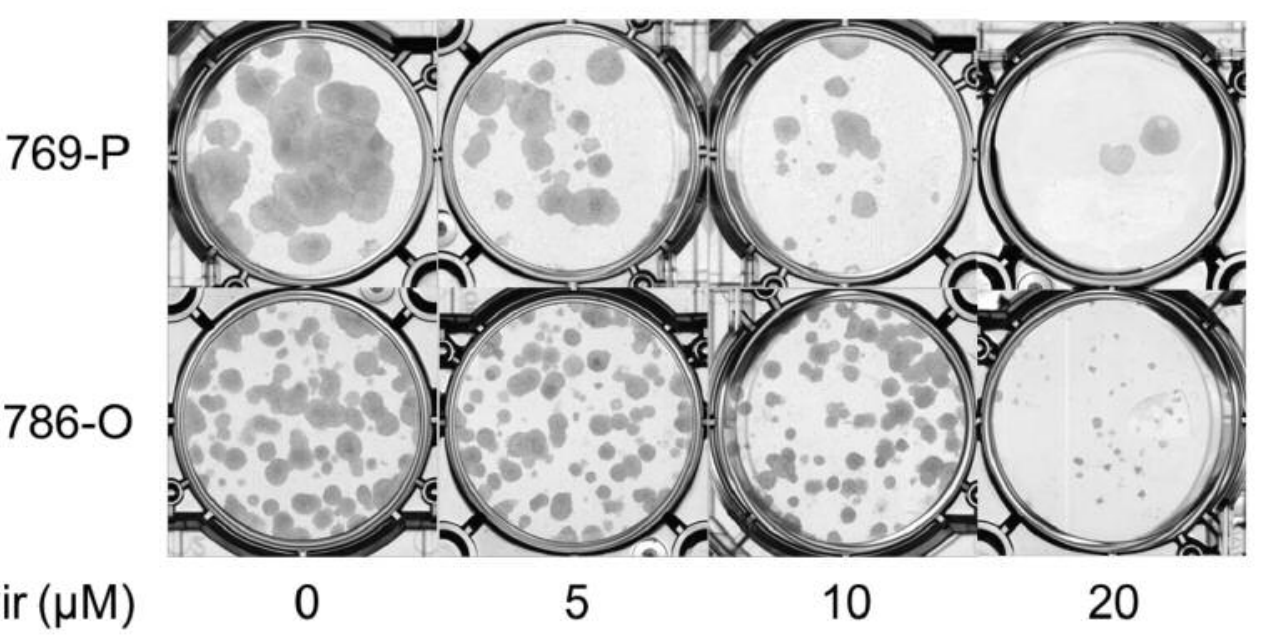

Nelfinavir $(\mu \mathrm{M})$

10

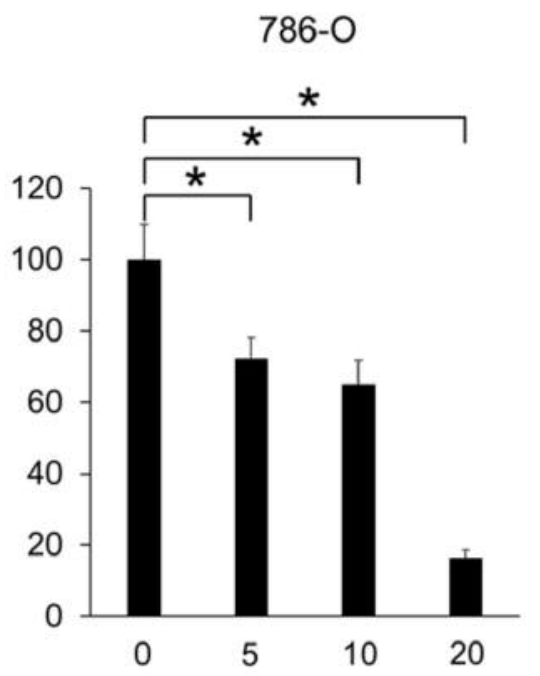

Nelfinavir $(\mu \mathrm{M})$

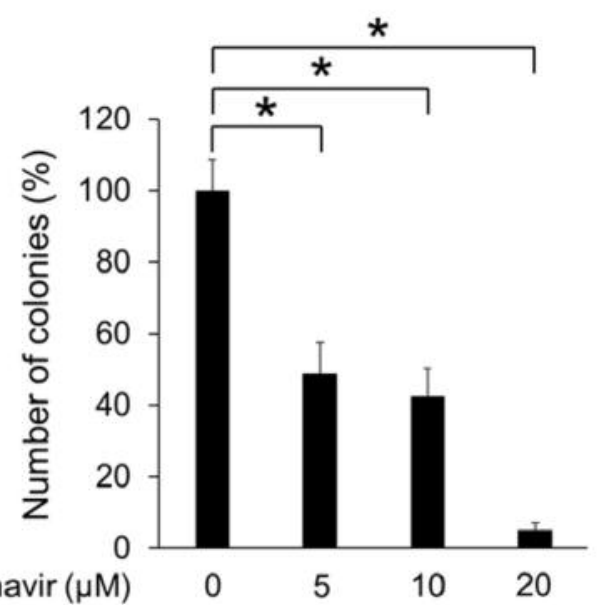

Figure 1. Nelfinavir had anti-proliferative activity against renal cancer cells. A: MTS assay. Cells were treated for $48 \mathrm{~h}$ with 2-20 $\mu \mathrm{M}$ nelfinavir. Bars represent mean $\pm S D, n=12$. B: Colony-formation assay. Cells were treated for $48 \mathrm{~h}$ with 5-20 $\mu \mathrm{M}$ nelfinavir, then given fresh media and allowed to grow for 1-2 weeks. Bars represent mean $\pm S D, n=3 . *$ Relative to the untreated control. 


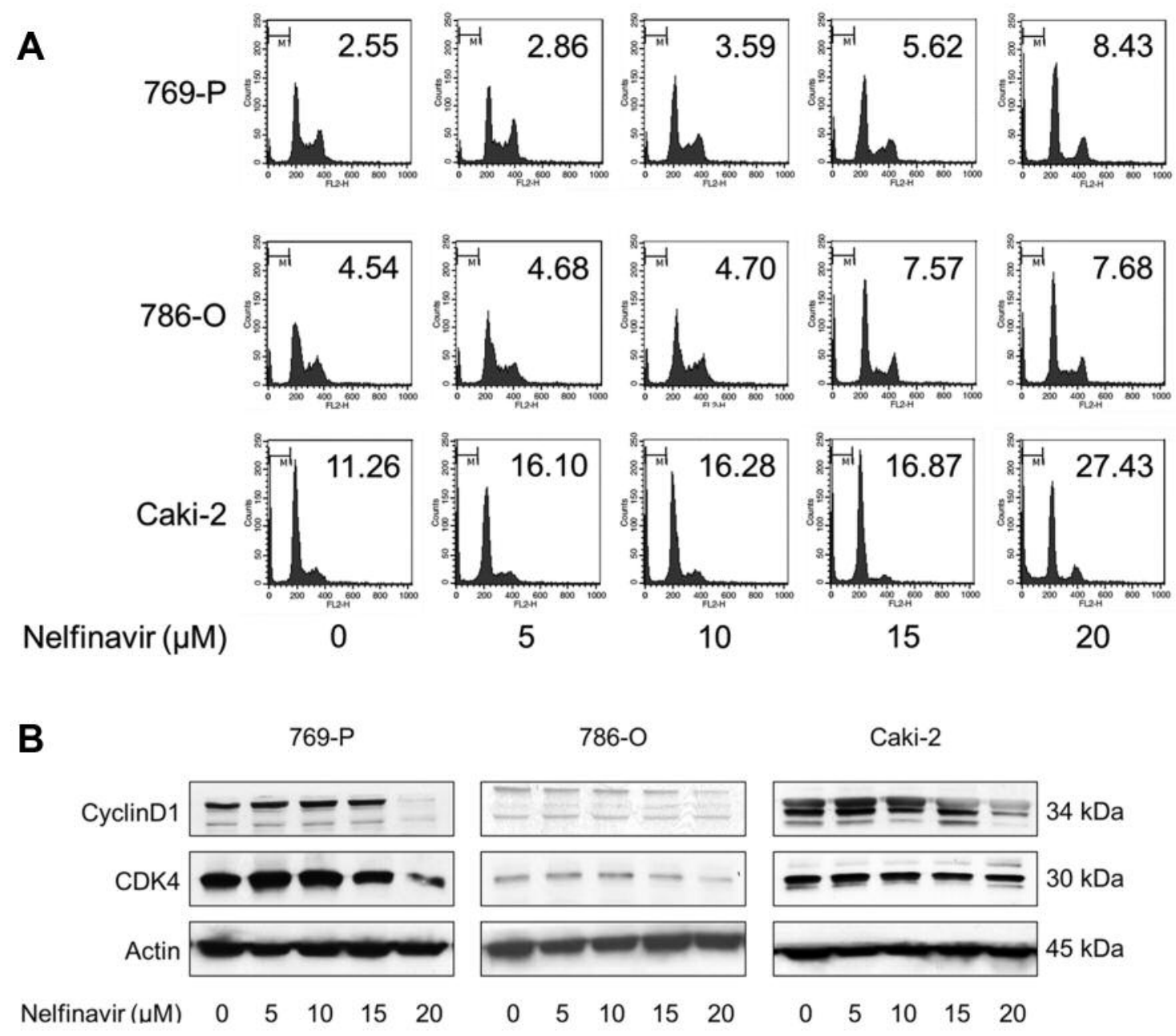

Figure 2. Continued

Nelfinavir caused aggresome formation and induced autophagy in renal cancer cells. Because unfolded proteins often aggregate and form aggresomes, we then evaluated nelfinavir-induced aggresome formation and autophagy. As expected, nelfinavir caused aggresome formation (Figure 4A) and induced autophagy (evidenced by the increased expression of the autophagy marker LC3-II) (Figure 4B). These results indicate that nelfinavir actually increases unfolded proteins in the cell.

Nelfinavir increased the expression of DR4 and DR5 and thereby sensitized renal cancer cells to TRAIL. ER stress has been reported to increase the expression of TRAIL receptors (15). We thought that nelfinavir would increase the expression of TRAIL receptors and thereby sensitize renal cancer cells to TRAIL. Treatment with nelfinavir for $48 \mathrm{~h}$ indeed increased the expression of the TRAIL receptors DR4 and DR5 in a dose-dependent fashion (Figure 5A). According to the MTS assay, $25 \mathrm{ng} / \mathrm{ml}$ TRAIL alone did not kill cancer cells. When the cells were pre-treated for $24 \mathrm{~h}$ with $20 \mu \mathrm{M}$ nelfinavir, however, TRAIL exerted strong cytotoxicity (Figure 5B). Furthermore, $1 \mu \mathrm{g} / \mathrm{ml} \mathrm{DR} 4 / \mathrm{Fc}$ or DR5/Fc chimeric protein attenuated nelfinavir-enhanced TRAIL cytotoxicity. The morphological change was also consistent with this sensitization: TRAIL alone had almost no effect on cell attachment, but cells treated with nelfinavir and TRAIL were floating, which was abrogated by DR4/Fc and DR5/Fc chimeric protein (Figure 5C). Annexin-V assay also confirmed this sensitization by nelfinavir: Treatment with TRAIL induced significant apoptosis only when it was preceded by nelfinavir treatment, and this apoptosis induction was significantly blocked by DR4/Fc and DR5/Fc chimeric protein (Figure 5D). 
C

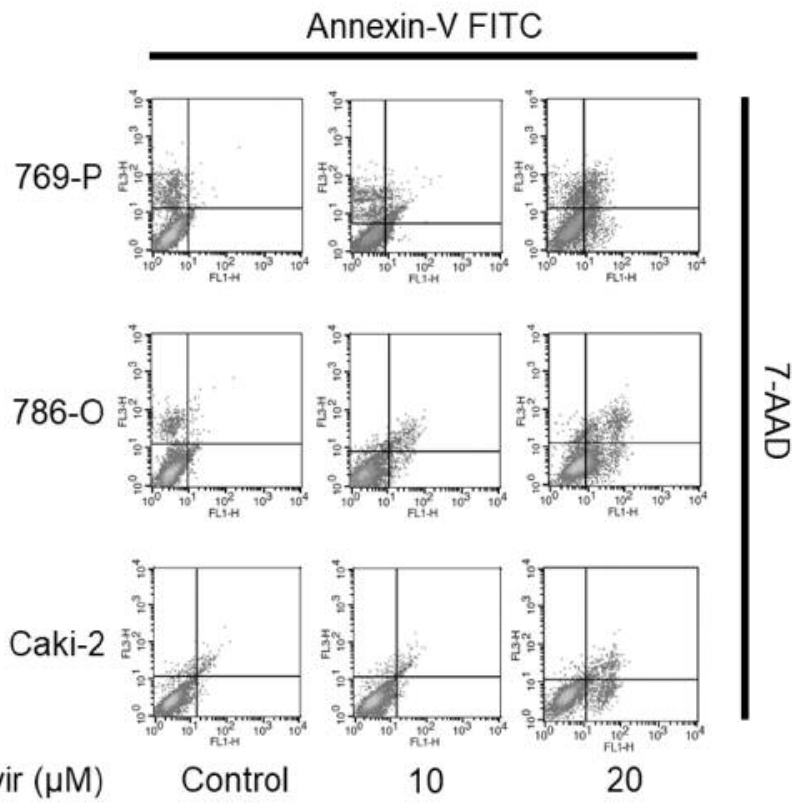

Nelfinavir $(\mu \mathrm{M}) \quad$ Control

10

定

769-P

$786-0$

Caki-2
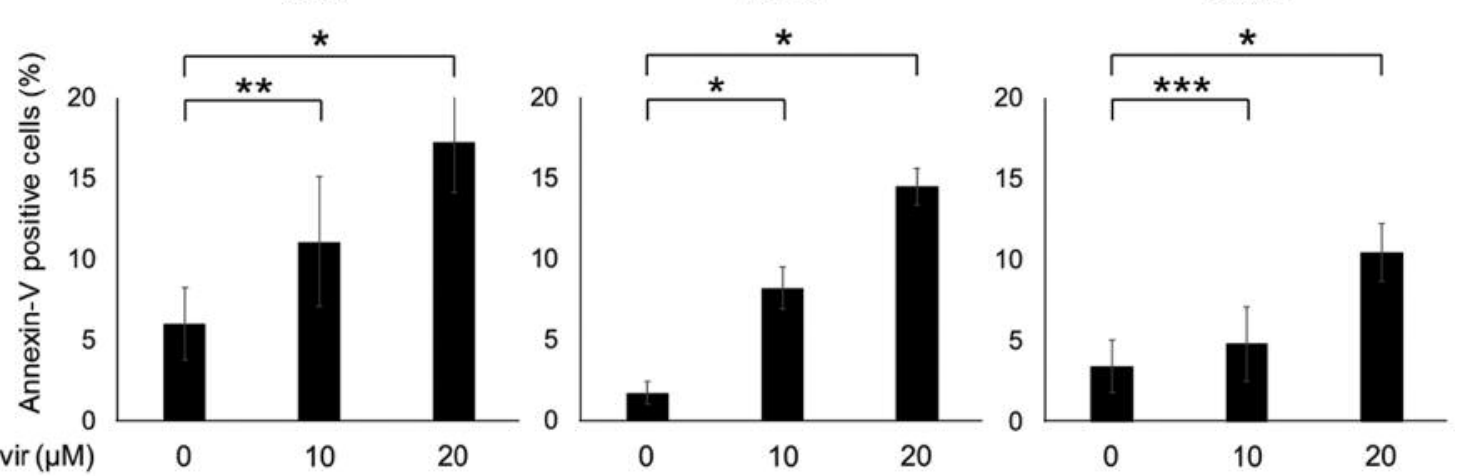

D

769-P

$786-\mathrm{O}$

Caki-2
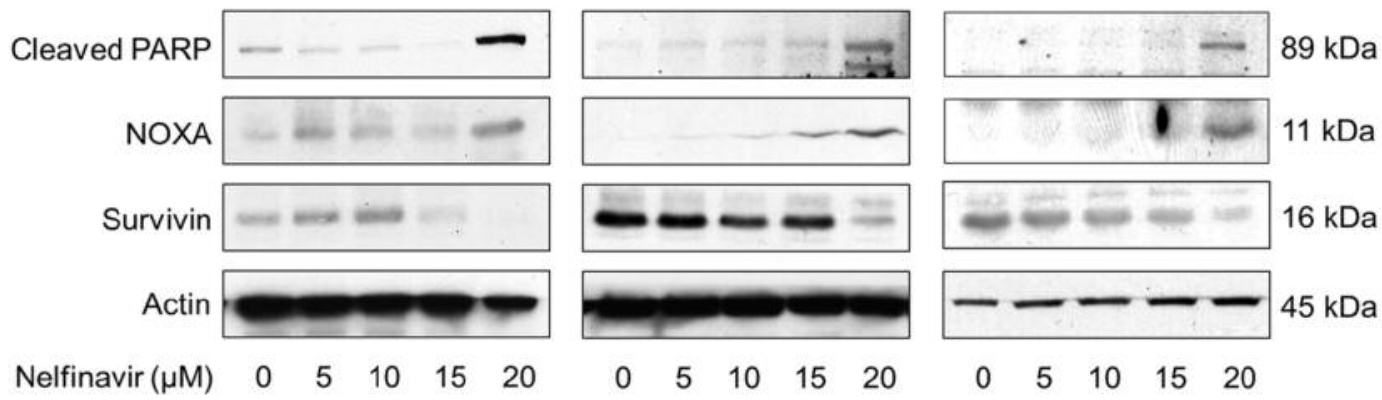

Figure 2. Nelfinavir induced apoptosis of renal cancer cells. A: Cell-cycle analysis. Cells were treated for 48 h with 5-20 $\mu M$ nelfinavir. Changes in the cell-cycle distribution were evaluated using flow cytometry; 10,000 cells were counted. The number inset in each graph shows the percentage of cells in the sub-G1 fraction. B: Western blotting for cyclin D1 and cyclin-dependent kinase 4 (CDK4). Cells were treated for $48 \mathrm{~h}$ with 5-20 $\mu \mathrm{M}$ nelfinavir. Actin was used as the loading control. Representative blots are shown. C: Annexin-V assay. Cells were treated for $48 \mathrm{~h}$ with 10 or $20 \mu \mathrm{M}$ nelfinavir. Apoptotic cells were detected by annexin-V assay using flow cytometry; 10,000 cells were counted. Bar graphs show the percentages of apoptotic cells. Data are expressed as mean $\pm S D$ from three independent experiments. FITC, Fluorescein isothiocyanate; 7-AAD, 7-amino-actinomycin D. D: Western blotting for cleaved poly(ADP-ribose) polymerase (PARP), phorbol-12-myristate-13-acetate-induced protein 1 (NOXA), and survivin. Cells were treated for $48 \mathrm{~h}$ with 5-20 $\mu \mathrm{M}$ nelfinavir. Actin was used for the loading control. Representative blots are shown. 


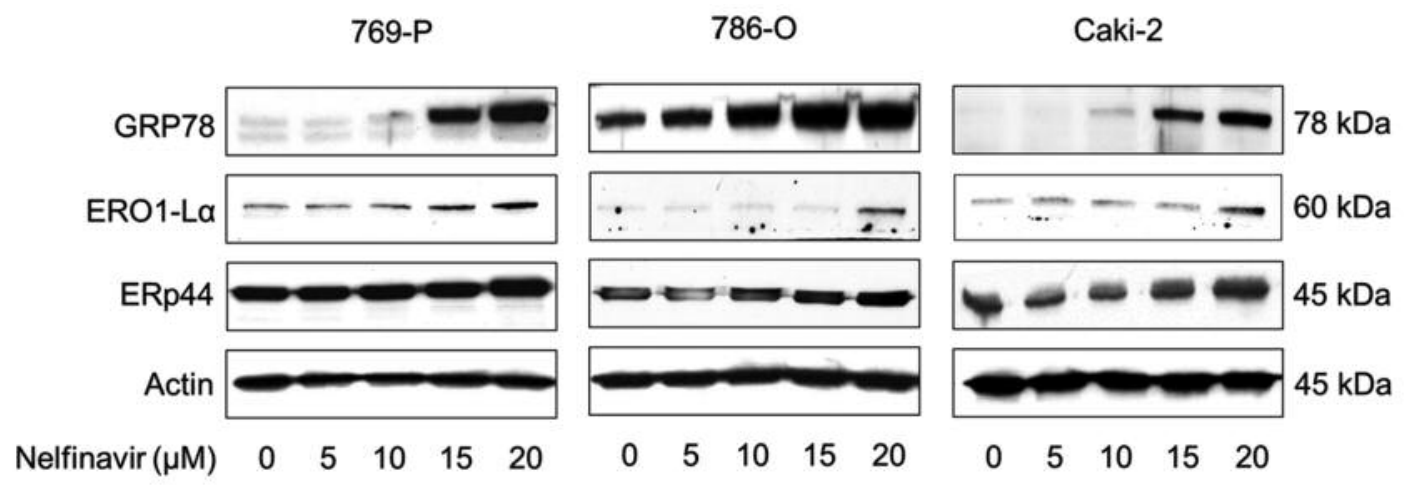

Figure 3. Nelfinavir induced endoplasmic reticulum (ER) stress in renal cancer cells. Western blotting for the ER stress markers glucose-regulated protein 78 (GRP78), endoplasmic oxidoreductin-1-like protein alpha (ERO1-La), and endoplasmic reticulum resident protein 44 (ERp44). Cells were treated for $48 \mathrm{~h}$ with 5-20 $\mu \mathrm{M}$ nelfinavir. Actin was used for the loading control. Representative blots are shown.

A

769-P

Nelfinavir $(\mu \mathrm{M})$
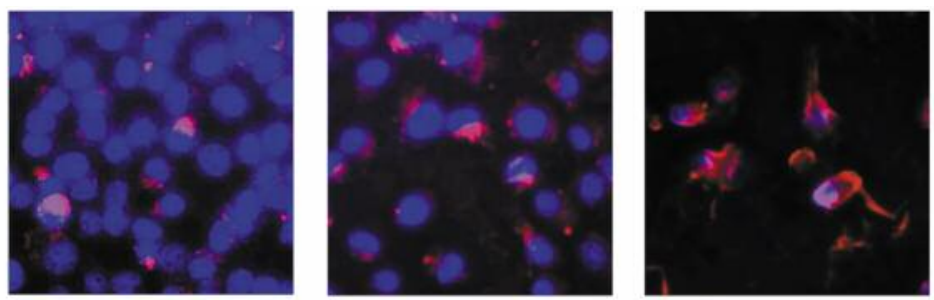

$786-\mathrm{O}$
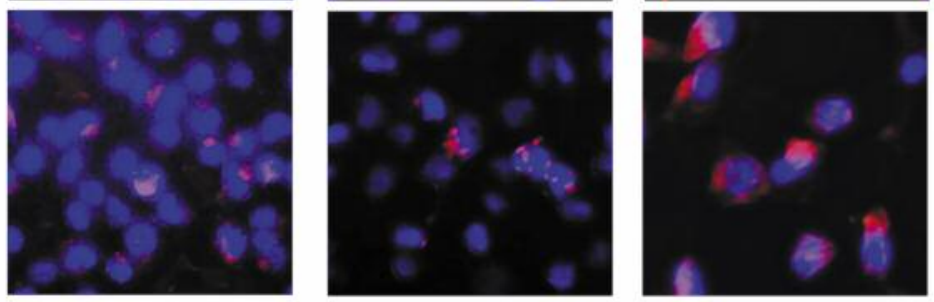

10

20

B

769-P

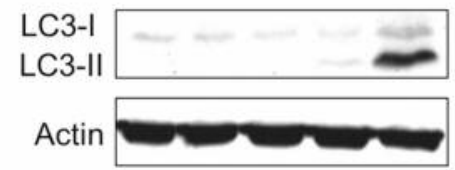

Nelfinavir $(\mu \mathrm{M}) \quad 0 \quad 5 \quad 10 \quad 15 \quad 20$
$786-0$

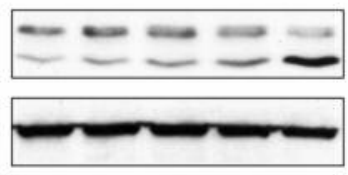

$\begin{array}{lllll}0 & 5 & 10 & 15 & 20\end{array}$
Caki-2

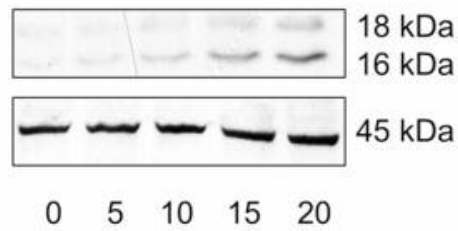

Figure 4. Nelfinavir caused aggresome formation and induced autophagy in renal cancer cells. A: Aggresome detection after $48 \mathrm{~h}$ treatment with 10 or $20 \mu \mathrm{M}$ nelfinavir. Red, aggresome; blue, nucleus. Original magnification, 100x. B: Western blotting for the autophagy marker light chain 3 (LC3). Cells were treated for $48 \mathrm{~h}$ with 5-20 $\mu \mathrm{M}$ nelfinavir. The emergence of LC3-II marks the occurrence of autophagy. Actin was used for the loading control. Representative blots are shown.

\section{Discussion}

A significant number of patients diagnosed with renal cancer present with locally invasive or metastatic disease (17), and novel therapeutic approaches are urgently needed because although tyrosine kinase inhibitors, mTOR inhibitors, and immune checkpoint inhibitors are widely used against advanced renal cancer (2-9), there is no curative therapy for it. Induction of ER stress reportedly killed cancer cells $(18,19)$ and has been recognized as a novel strategy for treating cancer 
A

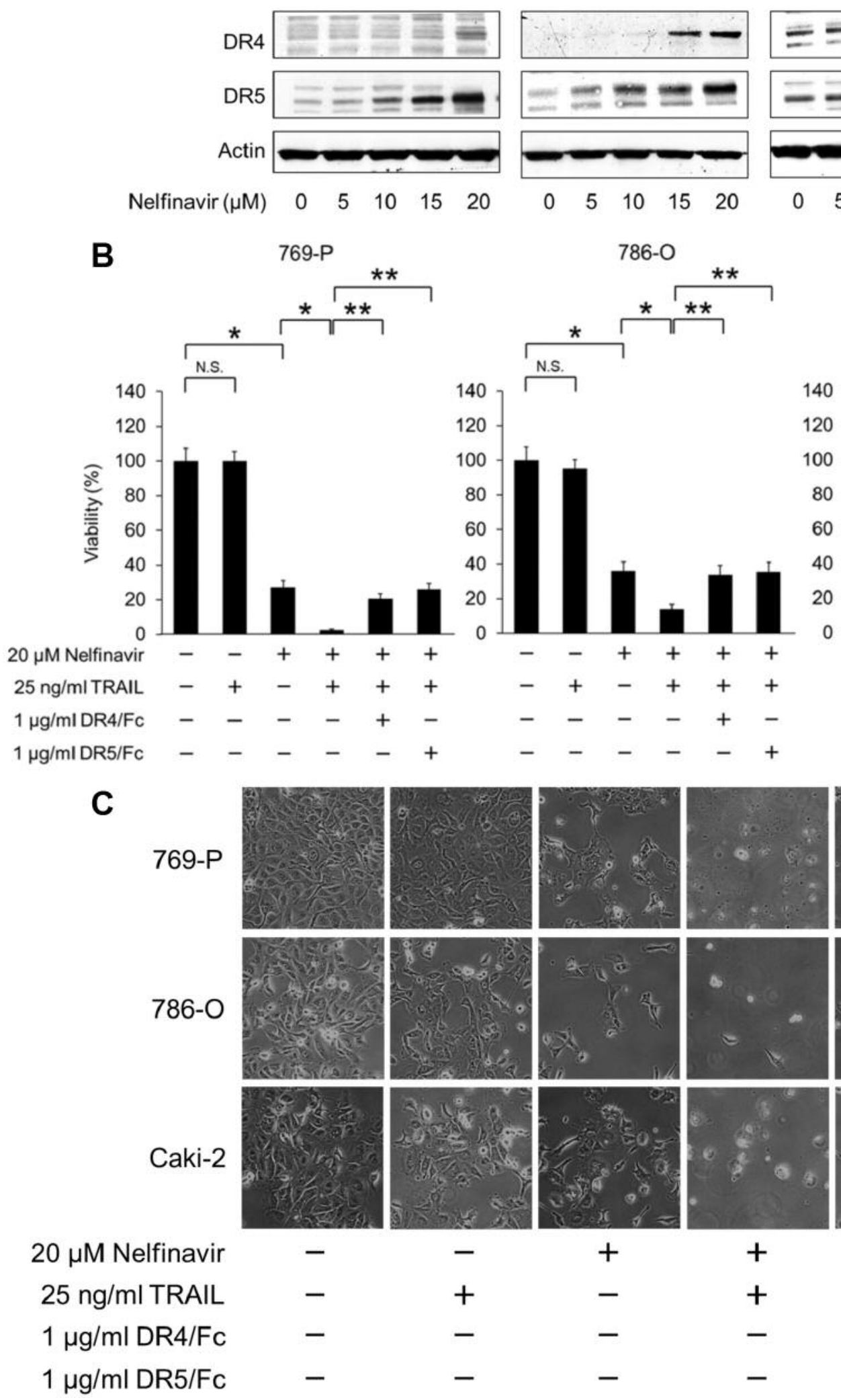

786-O

Caki-2 

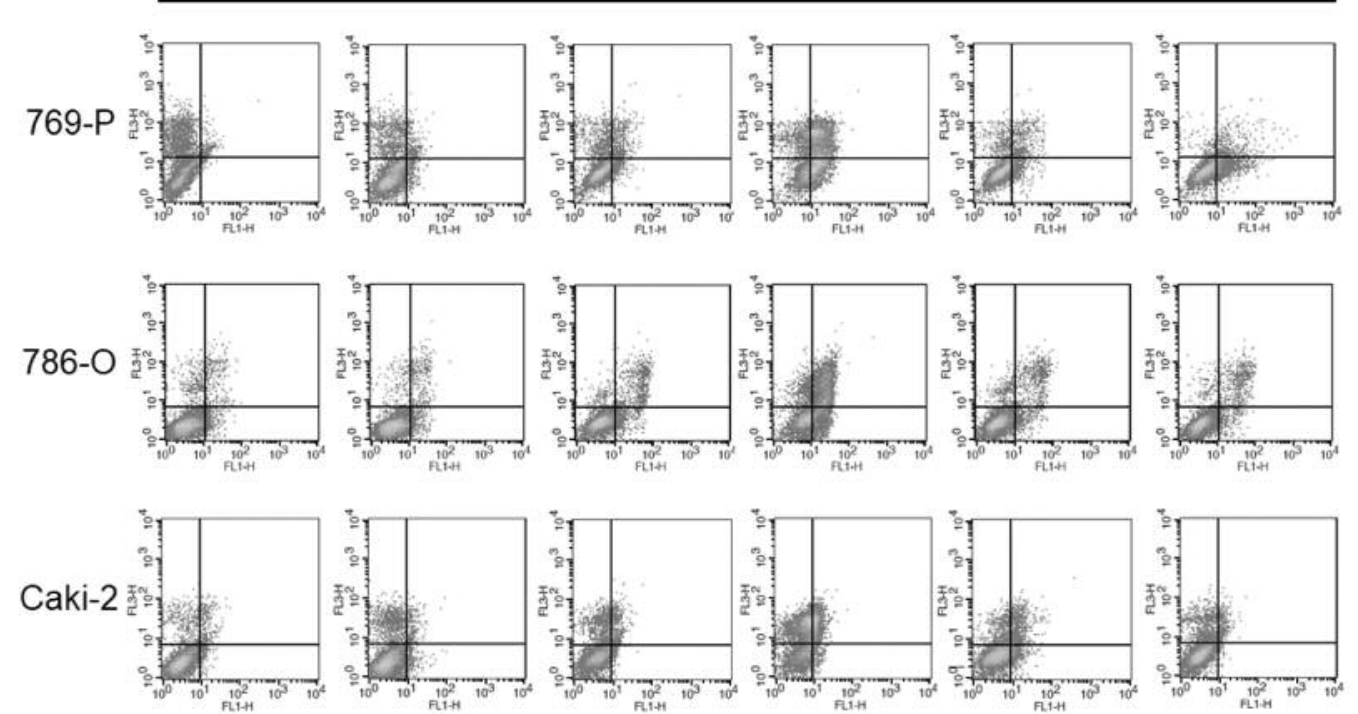

$\begin{array}{cc}20 \mu \mathrm{M} \text { Nelfinavir } & - \\ 25 \mathrm{ng} / \mathrm{ml} \text { TRAIL } & - \\ 1 \mu \mathrm{g} / \mathrm{ml} \text { DR4/Fc } & - \\ 1 \mu \mathrm{g} / \mathrm{ml} \text { DR5/Fc } & -\end{array}$

769-P

$786-0$

\section{Caki-2}

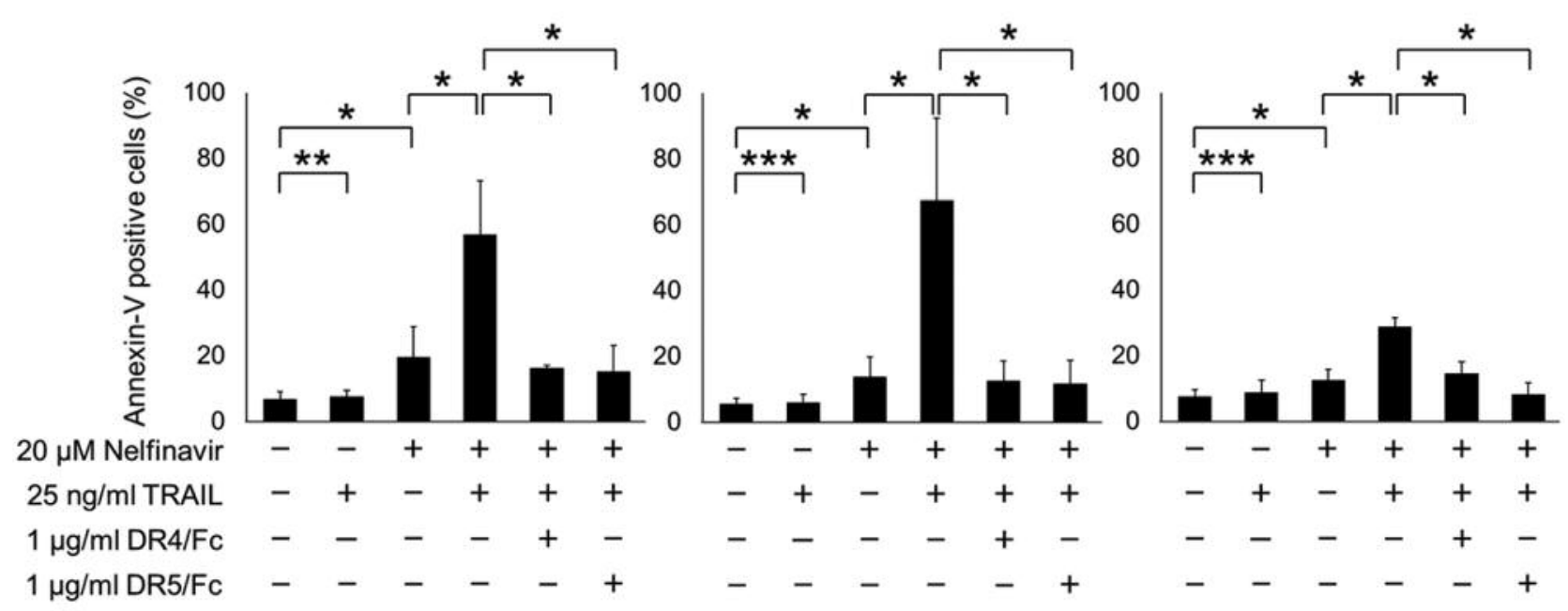

Figure 5. Nelfinavir increased the expression of death receptor 4 (DR4) and DR5 and sensitized renal cancer cells to tumor necrosis factor-related apoptosis-inducing ligand (TRAIL). A: Western blotting for DR4 and DR5. Cells were treated for $48 \mathrm{~h}$ with 5-20 $\mu \mathrm{M}$ nelfinavir. Actin was used as the loading control. Representative blots are shown. B: MTS assay. Cells were cultured for $24 \mathrm{~h}$ in medium with or without $20 \mu \mathrm{M}$ nelfinavir. Then they were given $25 \mathrm{ng} / \mathrm{ml}$ TRAIL with or without $1 \mu \mathrm{g} / \mathrm{ml} D R 4 / F c$ or DR5/Fc chimeric protein and incubated for another $24 \mathrm{~h}$. Bars represent mean $\pm S D, n=12$. Significantly different at $* p=0.0001, * * p=0.0007, * * * p=0.0033$, and $* * * * p=0.0021 ;$ N.S., not significantly different. C: Photomicrographs after $48-h$ treatment. Cells were cultured for $24 \mathrm{~h}$ in medium with or without $20 \mu \mathrm{M}$ nelfinavir. Then they were given $25 \mathrm{ng} / \mathrm{ml}$ TRAIL with or without $1 \mu \mathrm{g} / \mathrm{ml}$ DR4/Fc or DR5/Fc chimeric protein and incubated for another $24 \mathrm{~h}$. Note that TRAIL exerted very strong cytotoxicity only when it was preceded by nelfinavir treatment, and this cytotoxicity was blocked by $D R 4 / F c$ and $D R 5 / F c$ chimeric protein. Original magnification, 100x. D: Annexin-V assay. Cells were cultured for $24 \mathrm{~h}$ in medium with or without $20 \mu \mathrm{M}$ nelfinavir. Then they were given $25 \mathrm{ng} / \mathrm{ml}$ TRAIL with or without $1 \mu \mathrm{g} / \mathrm{ml}$ DR4/Fc or DR5/Fc chimeric protein and incubated for another $24 \mathrm{~h}$. Apoptotic cells were detected by annexin-V assay using flow cytometry; 10,000 cells were counted. Bar graphs show the percentages of apoptotic cells. Data are expressed as mean $\pm S D$ from three independent experiments. FITC, Fluorescein isothiocyanate; 7-AAD, 7-amino-actinomycin D. *Significantly different at $p=0.0495$; N.S., not significantly different. 
(10). The present study showed that the HIV protease inhibitor nelfinavir induced ER stress and killed renal cancer cells.

Nelfinavir is widely used against HIV infection and was recently found to exert antitumor activity by inhibiting proteasomes (11), HSP90 (12), the AKT serine/threonine kinase pathway (20), and nuclear factor-kappa B (NF-xB) (21). We believed that nelfinavir would inhibit both proteasomes and molecular chaperones and thereby cause unfolded proteins to accumulate in the cells. When unfolded protein accumulation is persistent, it triggers ER stress, resulting in cell death (22).

We found that nelfinavir induced apoptosis and inhibited the growth of renal cancer cells in a dose-dependent fashion. As postulated, nelfinavir induced ER stress, evidenced by the increased expression of the ER stress markers GRP78, ERO1L $\alpha$ and ERp44. We previously showed the importance of ER stress induction in inhibiting renal cancer growth (23-25), and the induction of ER stress is thought to be one important mechanism of action of nelfinavir. In addition, nelfinavir caused aggresome formation and induced autophagy. An aggresome is a cytoplasmic inclusion body containing unfolded protein aggregates (26), and it facilitates elimination of unfolded proteins from cells by autophagy $(27,28)$. The role of autophagy in cancer cells remains controversial, but excessive autophagy reportedly killed cancer cells (29). Although further study would be needed to clarify the exact role of nelfinavir-induced aggresome formation and autophagy, these phenomena well support our postulation that nelfinavir causes unfolded protein to accumulate in the cell.

TRAIL, as a member of the TNF family, can bind TRAIL receptors such as DR4 and DR5 and induce apoptosis in many kinds of tumor cells in vitro and in vivo (13). After binding its receptors, TRAIL activates caspase cascades (14), which accelerate apoptosis (30). ER stress was recently shown to regulate TRAIL receptors in malignant diseases (31-33), and we postulated nelfinavir might also increase the expression of TRAIL receptors in renal cancer cells. As expected, nelfinavir did induce ER stress and increased the expression of DR4 and DR5. Because TRAIL killed cancer cells only when they had been pretreated with nelfinavir and blockade of each of the receptors with the corresponding chimeras (DR4/Fc and $\mathrm{DR} 5 / \mathrm{Fc}$ ) attenuated TRAIL-induced cytotoxicity, the sensitization of renal cancer cells to TRAIL was shown to be due to the increased expression of both DR4 and DR5 caused by nelfinavir. In gastric cancer, overexpression of TRAIL- $\gamma$ in gastric carcinoma tissue samples was reported to be associated with a significantly higher survival rate (34). Anees et al. showed that elevated TRAIL expression in the tumor microenvironment was significantly associated with increased recurrence-free survival in patients with prostate cancer (35). Thus, intrinsic TRAIL is thought to have significant anticancer activity. Furthermore, patients with bladder cancer with high expression of DR4 or DR5 were shown to have significantly longer postoperative recurrence-free periods (36). Increasing the sensitivity of cancer cells to intrinsic TRAIL by using nelfinavir to increase the expression of TRAIL receptors is thus thought to be a reasonable approach to killing cancer cells through activation of the TRAIL pathway.

To our knowledge, this is the first study showing that nelfinavir induced ER stress in renal cancer cells and sensitized them to TRAIL. The present study provides a basis for clinical studies using nelfinavir in patients with renal cancer.

\section{References}

1 Ferlay J, Soerjomataram I, Dikshit R, Eser S, Mathers C, Rebelo M, Parkin DM, Forman D and Bray F: Cancer incidence and mortality worldwide: sources, methods and major patterns in GLOBOCAN 2012. Int J Cancer 136: E359-386, 2015.

2 Motzer RJ, Hutson TE, Tomczak P, Michaelson MD, Bukowski RM, Rixe O, Oudard S, Negrier S, Szczylik C, Kim ST, Chen I, Bycott PW, Baum CM and Figlin RA: Sunitinib versus interferon alpha in metastatic renal-cell carcinoma. $\mathrm{N}$ Engl $\mathbf{J}$ Med 356: 115-124, 2007.

3 Sternberg CN, Davis ID, Mardiak J, Szczylik C, Lee E, Wagstaff J, Barrios CH, Salman P, Gladkov OA, Kavina A, Zarbá JJ, Chen M, McCann L, Pandite L, Roychowdhury DF and Hawkins RE: Pazopanib in locally advanced or metastatic renal cell carcinoma: results of a randomized phase III trial. J Clin Oncol 28: 106-168, 2010

4 Rini BI, Escudier B, Tomczak P, Kaprin A, Szczylik C, Hutson TE, Michaelson MD, Gorbunova VA, Gore ME, Rusakov IG, Negrier S, Ou YC, Castellano D, Lim HY, Uemura H, Tarazi J, Cella D, Chen C, Rosbrook B, Kim S and Motzer RJ: Comparative effectiveness of axitinib versus sorafenib in advanced renal cell carcinoma (AXIS): a randomized phase 3 trial. Lancet 378: 1931-1939, 2011.

5 Hudes G, Carducci M, Tomczak P, Dutcher J, Figlin R, Kapoor A, Staroslawska E, Sosman J, McDermott D, Bodrogi I, Kovacevic Z, Lesovoy V, Schmidt-Wolf IG, Barbarash O, Gokmen E, O'Toole T, Lustgarten S, Moore L and Motzer RJ: Temsirolimus, interferon alfa, or both for advanced renal-cell carcinoma. N Engl J Med 356: 2271-2281, 2007.

6 Motzer RJ, Escudier B, Oudard S, Hutson TE, Porta C, Bracarda S, Grünwald V, Thompson JA, Figlin RA, Hollaender N, Urbanowitz G, Berg WJ, Kay A, Lebwohl D and Ravaud A: Efficacy of everolimus in advanced renal cell carcinoma: a double-blind, randomized, placebo-controlled phase III trial. Lancet 372: 449-456, 2008.

7 Fisher R, Gore $\mathrm{M}$ and Larkin J: Current and future systemic treatments for renal cell carcinoma. Semin Cancer Biol 23: 3845, 2013.

8 Mazza C, Escudier B and Albiges L: Nivolumab in renal cell carcinoma: latest evidence and clinical potential. Ther Adv Med Oncol 9: 171-181, 2017.

9 Motzer RJ, Escudier B, McDermott DF, George S, Hammers HJ, Srinivas S, Tykodi SS, Sosman JA, Procopio G, Plimack ER, Castellano D, Choueiri TK, Gurney H, Donskov F, Bono P, Wagstaff J, Gauler TC, Ueda T, Tomita Y, Schutz FA, Kollmannsberger C, Larkin J, Ravaud A, Simon JS, Xu LA, Waxman IM and Sharma P: Nivolumab versus everolimus in advanced renal-cell carcinoma. $\mathrm{N}$ Engl J Med 373: 1803-1813, 2015. 
$10 \mathrm{Kim}$ I, Xu W and Reed JC: Cell death and endoplasmic reticulum stress: disease relevance and therapeutic opportunities. Nat Rev Drug Discov 7: 1013-1030, 2008.

11 Gupta AK, Li B, Cerniglia GJ, Ahmed MS, Hahn SM and Maity A: The HIV protease inhibitor nelfinavir down-regulates AKT phosphorylation by inhibiting proteasomal activity and inducing the unfolded protein response. Neoplasia 9: 271-278, 2007.

12 Shim JS, Rao R, Beebe K, Neckers L, Han I, Nahta R and Liu JO: Selective inhibition of HER2-positive breast cancer cells by the HIV protease inhibitor nelfinavir. J Natl Cancer Inst 104: 1576-1590, 2012.

13 Rivoltini L, Chiodoni C, Squarcina P, Tortoreto M, Villa A, Vergani B, Bürdek M, Botti L, Arioli I, Cova A, Mauri G, Vergani E, Bianchi B, Della Mina P, Cantone L, Bollati V, Zaffaroni N, Gianni AM, Colombo MP and Huber V: TNFrelated apoptosis-inducing ligand (TRAIL)-armed exosomes deliver proapoptotic signals to tumor site. Clin Cancer Res 22: 3499-3512, 2016.

14 Elrod HA and Sun SY: Modulation of death receptors by cancer therapeutic agents. Cancer Biol Ther 7: 163-173, 2008.

15 Ma Z, Fan C, Yang Y, Di S, Hu W, Li T, Zhu Y, Han J, Xin Z, Wu G, Zhao J, Li X and Yan X: Thapsigargin sensitizes human esophageal cancer to TRAIL-induced apoptosis via AMPK activation. Sci Rep 6: 35196, 2016

16 Sato A, Oya M, Ito K, Mizuno R, Horiguchi Y, Umezawa K, Hayakawa M and Murai M: Survivin associates with cell proliferation in renal cancer cells: regulation of survivin expression by insulin-like growth factor-1, interferon-gamma and a novel NF-kappaB inhibitor. Int J Oncol 28: 841-846, 2006.

17 Cohen HT and McGovern FJ: Renal-cell carcinoma. N Engl J Med 353: 2477-2490, 2005.

18 Xipell E, Aragón T, Martínez-Velez N, Vera B, Idoate MA, Martínez-Irujo JJ, Garzón AG, Gonzalez-Huarriz M, Acanda AM, Jones C, Lang FF, Fueyo J, Gomez-Manzano C and Alonso MM: Endoplasmic reticulum stress-inducing drugs sensitize glioma cells to temozolomide through down-regulation of MGMT, MPG, and Rad51. Neuro Oncol 18: 1109-1119, 2016.

19 Vincenz L, Jäger R, O'Dwyer M and Samali A: Endoplasmic reticulum stress and the unfolded protein response: targeting the Achilles heel of multiple myeloma. Mol Cancer Ther 12: 831843,2013

20 Jensen K, Bikas A, Patel A, Kushchayeva Y, Costello J, McDaniel D, Burman $\mathrm{K}$ and Vasko $\mathrm{V}$ : Nelfinavir inhibits proliferation and induces DNA damage in thyroid cancer cells. Endocr Relat Cancer 24: 147-156, 2017.

21 Sgadari C, Monini P, Barillari G and Ensoli B: Use of HIV protease inhibitors to block Kaposi's sarcoma and tumour growth. Lancet Oncol 4: 537-547, 2003.

22 Mimnaugh EG, Xu W, Vos M, Yuan X, Isaacs JS, Bisht KS, Gius D and Neckers L: Simultaneous inhibition of hsp 90 and the proteasome promotes protein ubiquitination, causes endoplasmic reticulum-derived cytosolic vacuolization, and enhances antitumor activity. Mol Cancer Ther 3: 551-566, 2004.

23 Sato A, Asano T, Horiguchi A, Ito K, Sumitomo M and Asano $\mathrm{T}$ : Combination of suberoylanilide hydroxamic acid and ritonavir is effective against renal cancer cells. Urology 76 : 764.e7-13, 2010
24 Sato A, Asano T, Ito K and Asano T: Ritonavir interacts with bortezomib to enhance protein ubiquitination and histone acetylation synergistically in renal cancer cells. Urology 79: 966.e13-21, 2012.

25 Sato A, Asano T, Isono M, Ito K and Asano T: Panobinostat synergizes with bortezomib to induce endoplasmic reticulum stress and unfolded protein accumulation in renal cancer cells. BMC Urol 14: 71, 2014.

26 Johnston JA, Ward CL and Kopito RR: Aggresomes: a cellular response to misfolded proteins. J Cell Biol 143: 1883-1898, 1998.

27 Kawaguchi Y, Kovacs JJ, McLaurin A, Vance JM, Ito A and Yao TP: The deacetylase HDAC6 regulates aggresome formation and cell viability in response to misfolded protein stress. Cell 115: 727-738, 2003.

28 Moriya S, Komatsu S, Yamasaki K, Kawai Y, Kokuba H, Hirota A, Che XF, Inazu M, Gotoh A, Hiramoto M and Miyazawa K: Targeting the integrated networks of aggresome formation, proteasome, and autophagy potentiates ER stress-mediated cell death in multiple myeloma cells. Int J Oncol 46: 474-486, 2015.

29 Gozuacik D and Kimchi A: Autophagy as a cell death and tumor suppressor mechanism. Oncogene 23: 2891-2906, 2004.

$30 \mathrm{Su}$ RY, Chao Y, Chen TY, Huang DY and Lin WW: 5Aminoimidazole-4-carboxamide riboside sensitizes TRAIL-and $\mathrm{TNF} \alpha$-induced cytotoxicity in colon cancer cells through AMPactivated protein kinase signaling. Mol Cancer Ther 6: 15621571, 2007.

31 Kim IY, Kang YJ, Yoon MJ, Kim EH, Kim SU, Kwon TK, Kim IA and Choi KS: Amiodarone sensitizes human glioma cells but not astrocytes to TRAIL-induced apoptosis via CHOP-mediated DR5 up-regulation. Neuro Oncol 13: 267-279, 2011.

32 Lee JY, Jung KH, Morgan MJ, Kang YR, Lee HS, Koo GB, Hong SS, Kwon SW and Kim YS: Sensitization of TRAILinduced cell death by 20(S)-ginsenoside Rg3 via CHOPmediated DR5 up-regulation in human hepatocellular carcinoma cells. Mol Cancer Ther 12: 274-285, 2013.

33 Yoon MJ, Kang YJ, Kim IY, Kim EH, Lee JA, Lim JH, Kwon TK and Choi KS: Monensin, a polyether ionophore antibiotic, overcomes TRAIL resistance in glioma cells via endoplasmic reticulum stress, DR5 up-regulation and c-FLIP downregulation. Carcinogenesis 34: 1918-1928, 2013.

34 Krieg A, Mersch S, Wolf N, Stoecklein NH, Verde PE, am Esch JS 2nd, Heikaus S, Gabbert HE, Knoefel WT and Mahotka C: Expression of TRAIL-splice variants in gastric carcinomas: Identification of TRAIL- $\gamma$ as a prognostic marker. BMC Cancer 13: 384, 2013.

35 Anees M, Horak P, El-Gazzar A, Susani M, Heinze G, Perco P, Loda M, Lis R, Krainer $M$ and Oh WK: Recurrence-free survival in prostate cancer is related to increased stromal TRAIL expression. Cancer 117: 1172-1182, 2011.

36 Li Y, Jin X, Li J, Jin X, Yu J, Sun X, Chu Y, Xu C, Li X, Wang $\mathrm{X}$, Kakehi $\mathrm{Y}$ and Wu X: Expression of TRAIL, DR4, and DR5 in bladder cancer: Correlation with response to adjuvant therapy and implications of prognosis. Urology 79: 968.e7-15, 2012.

Received May 26, 2018

Revised June 15, 2018

Accepted June 19, 2018 